\title{
ALIGNING ENTREPRENEURIAL INTENTION TOWARDS SUSTAINABLE DEVELOPMENT AMONG MUSLIM YOUTH IN INDONESIA
}

\author{
Gunawan Baharuddin ${ }^{1}$ | University of Malaya - Malaysia \\ Asmak Ab. Rahman | University of Malaya - Malaysia \\ Corresponding author: gbaharuddin@gmail.com
}

\begin{abstract}
The purpose of this paper is to examine the influence of entrepreneurial intention of the youth Muslim on the realization of maqasid al-shariab in order to overcome poverty and unemployment problems to achieve the sustainable development agenda. This paper also attempts to fit in and enrich the literatures of entrepreneurial intention which integrates with maqasid al-shari'ah as the objectives of Islamic teachings. An exploratory method design and a deductive approach employed in this study with respondent of 740 Muslim students from five provinces in Indonesia. The findings illustrate that religious and moral motivations have become an inseparable variable for developing entrepreneurial intentions among young people. The analysis output also indicates that subjective norms as the strongest driver to influence Muslim youth entrepreneurial intention. In addition, this study also has policy-level implication both for related government institutions and the universities.
\end{abstract}

Keywords: Sustainable development, entrepreneurial intention, maqāsid al-shari'ah, Muslim youth.

\section{Introduction}

The concept of sustainable development contains two fundamental elements, they are development and sustainability. Both elements are related to one another, development does not exist without sustainability or vice versa. ${ }^{2}$ With the purpose to achieve this

\footnotetext{
${ }^{1}$ I would like to express gratitude to the Indonesia Endowment Fund for Education (LPDP) for providing a scholarship for my $\mathrm{PhD}$ program.

2 W. Sachs, "Environment," in The Development Dictionary: A Guide to Knowledge as Power, ed. W. Sachs, 2nd ed. (London: Zed Books, 2010), 24-37.
} 
sustainable development, there are three fundamental concepts taken from the triple bottom line concept that should be highlight, namely environmental sustainability which concerns on the quality preservation of environment, social sustainability that guarantees human rights fairly, preservation of cultural identity, respect for diversity, race and religion, and the third concept is economic sustainability in which natural, social capital, and humans are the focus of attention. To achieve these objectives is not easy because every pillar of sustainability must also consider the interests of other pillars to make it remains balanced. ${ }^{3}$

One element that is quite important to be considered in efforts to create sustainable development is youth as the next generation which part of the concept of economic sustainability. Due to the dynamic changes and sophistication of world such as factors of industrialization, urbanization and digital environmental, the youths face a never-ending challenge of unemployment in addition to other social problems such as health, drug abuse and criminals act.

Youth empowerment is expected to address several social problems in the society and respond to the achievement of the targeted SDGs. Out of 17 goals, the consequences of youth empowerment might cover several goals in the short term for instance decent work and economic growth (SDG 8), enhancement infrastructure and innovation (SDG 9), sustainable production and consumption (SDG 12) and in the long run may meet the target of no poverty (SDG 1), zero hunger (SDG 2), good health and well-being (SDG 3), and reduced inequalities (SDG 10). In fact, development agenda for engagements and consultations that prioritize the youth since 2015 did not provide a comprehensive solution to the problems of youth development, especially those related to socio-political and economic development of global trends, such as low levels of participation in government, social deprivations, unemployment and other youth development problems in both developed and developing countries. ${ }^{4}$

\footnotetext{
3 Thomas Klarin, "The Concept of Sustainable Development: From Its Beginning to the Contemporary Issues," Zagreb International Review of Economics \& Business 21, no. 1 (2018): 67-94.

${ }^{4}$ K. Gough, T. Langevang, and G. Owusu, "Youth Employment in a Globalising World," International Development Planning Review 35, no. 2 (2013): 91-102; B. Bersaglio, C. Enns, and T. Kepe, "Youth Under Construction: The United Nations'
} 
Reasons to study youth in Indonesia because at the moment there has been demographic bonus where the productive age of the population (15-64 years old) is double than the unproductive age (lower than 15 years old and up to 65-year-old) and this conduction predicted will continue until 2035. ${ }^{5}$ Another reason is the entrepreneurship itself. Indonesia has been proved its resiliency and survival ability of small business enterprises during the hit of global crisis in 1998. The SMEs, which are domestic-based market (several have export demands) provided jobs for about 91.8 million people or $97.3 \%$ of the labor force in Indonesia and contributed to the GDP of an estimated $53.6 \%$ of the total GDP. ${ }^{6}$

Contrary with these potential powers such abundant human and natural resources, number of open unemployment was 7.05 million people or $5.28 \%$ of the total workforce reported by the CORE Indonesia in August 2019. This does not include the underemployed number of 8.14 million, and part-time workers of 28.41 million people. Even worse by the hit of the global pandemic Covid-19 to the economy, CORE Indonesia estimates an increase of open unemployment in the second quarter of 2020 in three scenarios. Potential increase of open unemployment nationally reaches 4.25 million people with mild scenarios, 6.68 million people with moderate scenarios, and even up to 9.35 million people with severe scenarios. ${ }^{7}$ In addition, the impact of the Covid-19 pandemic on the loss of workers in the informal sector needs to be more vigilant. Because the economic endurance of workers in the informal sector is relatively fragile, especially those that depend on daily income, mobility of people, and the activities of people who work in the formal sector. Moreover, the number of workers in the informal sector in Indonesia is greater than the formal sector workers, reaching 71.7 million people or $56.7 \%$ of

Representations of Youth in the Global Conversation on the Post-2015 Development Agenda," Canadian Journal of Development Studies 36, no. 1 (2015): 57-71.

${ }^{5}$ BPS, Statistical Yearbook of Indonesia, 2017.

${ }^{6}$ A. Azis and A. R. Haerani, Peranan Bank Indonesia Di Dalam Mendukung Pengembangan Usaha Mikro, Kecil, Dan Menengah, Kebanksent. (Jakarta, Indonesia: Pusat Pendidikan dan Studi Kebanksentralan (PPSK), 2009).

7 “Core Indonesia," accessed August 12, 2020, https://www.coreindonesia.org/view/468/waspada-lonjakan-pengangguran-dam $\% 1 \mathrm{Fpa} \% 1 \mathrm{Fk} \% 1 \mathrm{~F} \% 1 \mathrm{~F}-\% 1 \mathrm{~F} \% 1 \mathrm{Fpan} \% 1 \mathrm{~F}$ demi-covid-19-lima-rekomendasi-core. 
the total workforce and majority of them work in micro scale businesses.

Based on this issue, the purpose of this paper is to study the driving factors of youth to enhance their entrepreneurial intention in order to achieve the sustainable development agenda by reducing its unemployment problem. To achieve its objective, this study employed an empirical approach using partial least square-structural equation modeling (PLS-SEM) data analysis to assess the correlation between the variables tested: personal attitude, subjective norms, perceived behavioral control and entrepreneurial intention. The TPB model is believed provides better explanation of how the development of entrepreneurial intention compare to others model. Likewise, PLSSEM seemed most appropriate to measure the influence power of each variable and the path relationship between variables tested. However, this paper also proposes a model to fit in and enrich the literatures of entrepreneurial intention with additional independent variable of maqäsid al-shari $\bar{a}$ ah as the objectives of Islamic teachings. Numbers of studies have been written on the field of entrepreneurial intention, but analyses of the correlation of entrepreneurial intention and maqasid alshari'ah remain rare.

The contribution of this article is twofold. First, it gives another perspective in the literature of entrepreneurial intention using the theory of planned behaviour (TPB) with additional independent variable from Islamic view toward sustainable development. The second contribution is empirical: while the TPB model is commonly used in this field, employing Muslim youth in the context of Indonesia provides a more extensive empirical perspective.

To answer the research problem, this study used an exploratory method design with a deductive approach. 740 respondents were collected using clustered random sampling in two months and identified as the youth population with age range from 19 to 24 years old, narrowed down to students under Islamic universities. With the constraint of the huge areas of Indonesia, top five provinces with the highest number of students are chosen namely, East Java, West Java, Central Java, South Sulawesi, and Aceh. Later the final data to be used is 727 respondents due to invalid answers. 
In the instrument development, for a personal attitude measurement, this study adopts construct questions from Shinnar, Giacomin, and Janssen ${ }^{8}$ where four latent constructs are used under the exogenous driver of behavioral belief, namely "autonomy", "money", "challenges" and "life work balance". For subjective norms measurement, this study adopted the construct questions from Carsrud and Braannback" with three dimensions of the "social norms", indicating figure as a role model, entrepreneurial experiences in the family, and environment support. For perceived behavioral control measurement, this study adopted construct questions from Muller ${ }^{10}$ where four latent dimensions of the control belief is asserted to construct this variable, namely "self-competency", "business connection", "capital", and "government support." Six items were adopted from Linan and Chen ${ }^{11}$ to measure the entrepreneurial intention.

To asses the validity of the measurements, two phases will be employed, namely reflective measurement model and structural assessment model. Composite Reliability and Cronbach's Alpha were examined and the values generated between 0.7-0.9, and none of them lies below 0.6 which indicated as lack of internal consistency reliability or considered poor. In order to achieve adequate convergent validity, ${ }^{12}$ Hair et al. explain, each construct must cover at least 50 percent of the assigned indicator's variance (AVE $\geq 0.50$ ). Some thumb of rules has been applied in study, where an item construct was deleted because the loading value was below 0.4 , only if the AVE was still under 0.5 .

8 R. S. Shinnar, O. Giacomin, and F. Janssen, "Entrepreneurial Perceptions and Intentions: The Role of Gender and Culture," Entrepreneurship Theory \& Practice 36, no. 3 (2012): 465-493.

9 A. Carsrud and M. Braannback, "Entrepreneurial Motivations: What Do We Still Need to Know?," Journal of Small Business Management 49, no. 1 (2011): 9-26.

10 T. Muller, "Religiosity and Attitudes Towards the Involvement of Religious Leaders in Politics: A Multilevel-Analysis of 55 Societies," World Values Research 2, no. 1 (2009): $1-29$.

11 F. Linan and Y. W. Chen, "Development and Cross-Cultural Application of a Specific Instrument to Measure Entrepreneurial Intentions," Entrepreneurship Theory and Practice 33, no. 3 (2009): 593-617.

12 J.F. Hair et al., A Primer on Partial Least Square Structural Equation Modeling (PLS-SEM) (Sage Publications, 2017). 
Discriminant validity refers to the extent to which indicators are distinguished from each other, or in a simply means the construct under investigation are truly distinct from one another. In Smart PLS 3.0, three types of criteria are available to assess discriminant validity such as cross loading criterion where outer loading for each indicator is greater than others associated construct of its cross-loadings, FornellLarcker's criterion where AVE of a latent variable must be higher than the squared correlation between the latent variable and all other variables and Heterotrait-Monotrait ratio of correlation (HTMT) where all correlation indicators across the construct measure geometrically differently.

An assessment of the structural model was carried out to analyze the relationship between the latent constructs studied as well as to show the predictive power of the model from the variable proposed. However, before analysis of the structural model is applied, it is necessary to examine few steps. Step 1: Assess structural model for colliniearity issues. Step 2: Asses the significance and relevance of the structural model relationship. Step 3: Assess the level of $R^{2}$. Step 4: Assess the $f^{2}$ effect size. Step 5: Assess the predictive relevance $Q^{2}$.

\section{The Concept of Sustainable Development}

The theme of development mostly related with the classical western concept which focuses on infrastructure development, political power, and economic policy as an excellent tool for serving imperialist, thus marginalization and subtraction power of certain countries were the results. ${ }^{13}$ The implementation of this concept of development mainly occurred in economic sector through the transformation of traditional agriculture into the production of various modern industrial products and services. In other words, there has been switching from traditional society to the stage of maturity with high consumption. ${ }^{14}$ Based on that condition,Sharpley ${ }^{15}$ argues that there is counterproductive between development and sustainability

\footnotetext{
13 Sikandar Tangi, "Introduction to Development Studies," Scientific Network Academia.Edu.

14 M.P. Todaro and S.C. Smith, Economic Development, 8th ed. (Harlow: Pearson Education limited, 2003).

15 R. Sharpley, "Tourism and Sustainable Development: Exploring the Theoretical Divide," Journal of Sustainable Tourism 8, no. 1 (2000): 1-19.
} 
even though neoclassical economists assumed there is not. Furthermore, Sachs ${ }^{16}$ suggests that there is no development without sustainability or sustainability without development. Development is a process that ultimately results in the improvement of quality of life as well as economic capacity independently which depends on global integration, ${ }^{17}$ but each activity can be done by considering its longterm repetition and renewal without leading it to self-destruction. ${ }^{18}$

The term of sustainable development was introduced firstly from an ecological perspective and the International Union for Conservation of Nature mentioned it in 1980 in the Nature Conservation and Natural Resources Strategy and later it spread into the field of social and economic aspect. ${ }^{19}$ Considering the significant importance of economic empowerment towards substantial development, entrepreneurial intervention has been increasingly emphasized especially by the United Nations (UN) to encourage youth's desires to start their own business thus creates more opportunities on employment for others in the future. ${ }^{20}$ In fact, the contribution of entrepreneurship has been proved in social advancement and positively impacts in the areas of financial inclusion, women empowerment, sustainable farming, minority integration and many more. ${ }^{21}$ Entrepreneurship therefore in particular has a direct positive impact on the Sustainable Development Goals such as poverty alleviation (SDG 1), economic development and unemployment reduction (SDG 8), infrastructure improvement and innovation (SDG 9), social equality and inclusion (SDGs 5 and 10) and sustainable production and consumption (SDG 12) to be specified.

\footnotetext{
16 Sachs, "Environment."

${ }^{17} \mathrm{~J}$. Remenyi, "What Is Development?," in Key Issues in Development, ed. D. Kingsbury et al. (Hampshire, New York: Palgrave Macmillan, 2004), 22-44.

18 Klarin, "The Concept of Sustainable Development: From Its Beginning to the Contemporary Issues."

${ }^{19}$ Ibid.

20 United Nations, World Youth Report: Youth and the 2030 Agenda for Sustainable Development (New York, NY, 2017).

21 N. Apostolopoulos et al., "Entrepreneurship and the Sustainable Development Goals," in Entrepreneurship and the Sustainable Development Goals (Bingley, UK: Emerald Publishing Limited, 2018), 1-7.
} 


\section{The Sustainable Development in Islamic Views}

In Islam and for Muslims, sustainable development is not a new concept. There are hundred verses in the Quran and examples from the life of the Prophet Muhammad (PBUH) that give guidance to humans about how to interact each other as well as with the environment. The general concept of sustainable development consists of three important aspects: namely social, economic and environmental. However, Islam emphasizes the spiritual aspect as a compulsory need that plays a role in the process of development. Human spiritual development means the process of achieving complete knowledge of God and His attributes, and absolute belief in Him which must be translated into actions that follow the Quran's outlines and guidelines. ${ }^{22}$ Accordingly, preservation of sustainable development is the process of safeguarding God's creation and managing it in a way that is guided in the teachings of Islam so that development or progress leads to a better life with attention to basic human needs without only fulfilling interests and oriented to one's benefit, but must be sustainable.

In order to serve the interests of all human beings and save them from harm, maqäsid al-shari'ah provides the logical framework in the perspective of Islam. Several scholars define this term from their own perspectives. Abu Hamid al-Ghazali is the well-known scholar who defines maqasid by stressing the shari' ah concerning on promote wellbeing of the people, which lies in safeguarding their faith $(d \overline{i n})$, their lives (nafs), their intellect ( $a q)$ ), their posterity (nas), and their wealth (māt). In a broader dimension, Ibn-Ashur defines maqasid al-shari $a b$ as the objectives in principle (maqsad 'amm) of Islamic legislation, which protects the social order by promoting well-being and righteousness of human beings. The soundness of intellects, the righteousness of deeds, and the goodness of things in the world where human live are some of the supporting aspects in developing welfare. ${ }^{23}$

\footnotetext{
${ }^{22} \mathrm{Hj}$ Ab Rahman. Asyraf et al., "Sustainable Development From Islamic Perspective," International Journal of Civil Engineering and Technology 9, no. 4 (2018): 985-992.

23 Muhammad Al-Tahir Ibn Ashur, Treatise on Maqasid Al-Shariah, ed. Dr. Anas S. alShaikh-Ali and Shiraz Khan, IIIT Books. (The International Institute of Islamic Thought (IIIT), 2013); Abad Badruzaman, "Toward an Indonesian Current in Islamic Exegesis: An Attempt to Contextualize the Maqasid Al-Quran," Journal of Indonesian Islam 13, no. 2 (2019).
} 
Similarly, 17 SDGs targeted goals by the UN are ultimately aim the well-being of human beings, means that the people and their wellbeing as the end of development. Seven SDGs are actually the ultimate development goals which narrow down to people's well-being and the rest of the goals are intended to reach that ultimate. ${ }^{24}$ Human development in the perspective of Islam, maqasid al-shari'ab also employs as a theoretical foundation to generate an instrument to measure the quality of human development and its progress. Three levels of human needs namely primary need (daririyah), secondary need (hajiyah), and tertiary need (tahsiniyah) are the epicentral concern, but daruriyah is the fundamental one that people cannot live normally without them. Consequently, by fulfilling the daruriyah needs will lift the person or a family to above the poverty line.

Several works have been introduced to promote human well-being in the perspective of Islam. Among them are as follow: (1) the development of Islamic Human Development Index (I-HDI) which measures such as faith index, life index, science index, family social index, property index, freedom index and environment index; ${ }^{25}$ (2) the Posterity Development Index (PDI) which measures the level of development of future generations in terms of socio-economic, health and environmental aspects; ${ }^{26}$ (3) Maslahah-Based Development Index (M-Dex) as the extension of the existing Human Development Index (HDI) with a complementary model from the Islamic perspectives; ${ }^{27}$ and (4) Maqasid Shariah Index (MSI) which derives from the five main

24 Atih Rohaeti Dariah, Muhammad SyukriSalleh, and Hakimi M.Shafiai, "A New Approach for Sustainable Development Goals in Islamic Perspective," Procedia-Social Behavioral Sciences, no. 219 (2016): 159-166.

25 A. Hendrie, "Introducing an Islamic Human Development Index (I-HDI) to Measure Development in OIC Countries," Islamic Economic Studies 19, no. 2 (2011): 118.

${ }^{26}$ Z. Khan and Z. Bahari, "Maqasid Shariah Based Development Index: A Posterity Dimension.," in Policy Discussion Papers on Maqasid Shariah for Socio-Economic Development, ed. Abdul Ghafar Ismail, Salman Syed Ali, and Latifa Bibi (Saudi Arabia: IRTI-IDB, 2016); Zakaria Syafei, "Tracing Maqasid Al-Shari'ah in the Fatwas of Indonesian Council Of Ulama (MUI)," Journal of Indonesian Islam 11, no. 1 (2017).

${ }^{27}$ M.R. Raudha, A.G. Ismail, and M. Tasrif, "Maslahah-Based Development Index (MDex) Among The Islamic Countries," in Policy Discussion Papers on Maqasid Shariah for Socio-Economic Development, ed. Abdul Ghafar Ismail, Salman Syed Ali, and Latifa Bibi. (Saudi Arabia: IRTI-Islamic Development Bank, 2016). 
dimensions namely: faith, life, intellect, posterity and property to measure the performance of socio-economic policies. ${ }^{28}$ In sum, all of these instruments employ five preservation of human popularized by Al-Ghazali. Accordingly, sustainable development from the Islamic perspective indicators in this study adopts the protection of five aspects to achieve al-falah (well-being) namely, protection of faith, soul, intellect, progeny and wealth consisting of factors such as value, moral, and religious behavior, which have been included in these five aspects.

A lack of empirical researches that correlates entrepreneurial intention and sustainable development especially in the perspective of Islam derive this study to explore further because relationship between religion and economic activities is an intriguing topic which has significant influence in making daily life decisions. Salimath and Cullen $^{29}$ argued that levels of religiosity are positively related to entrepreneurial outcomes where moral virtues are pursued not for the sake of generating more profit but as an end in themselves. From the perspective of religion, striving to succeed in entrepreneurship in this world may result to success in the afterlife. ${ }^{30}$ Some studies in Indonesia have observed entrepreneurial intention among Muslim students using the TPB model.

The work of Wibowo ${ }^{31}$ has revealed that religious groups have stronger entrepreneurial intentions with lower dispersion than students who are not religious. The categorisation of religious or irreligious respondents was based on their view on the importance level of religiosity in daily life. He samples 412 Muslim students at the Faculty of Economic and Business at the University of Indonesia. Another

${ }^{28}$ M Nizam, I., \& Larbani, "A Maqasid Shariah Based Composite Index to Measure Socio-Economic Prosperity in OIC Countries," in Policy Discussion Papers on Maqasid Shariah for Socio-Economic Development, ed. Abdul Ghafar Ismail, Salman Syed Ali, and Latifa Bibi (Saudi Arabia: IRTI-IDB, 2016).

29 M.S. Salimath, and J. B. Cullen, "Formal and Informal Institutional Effects on Entrepreneurship: A Synthesis of Nation-level Research," International Journal of Organizational Analysis 18 2010): 358-385.

30 E.O. Lucky, "Nurturing Entrepreneurship Development in the 21st Century: The Practical Approaches," International Journal of Humanities and Social Science, 1, (2011): 219227.

31 B. Wibowo, "Religiosity and Entrepreneurial Intention," Etikonomi Jurnal Ekonomi, vol. 16 , no. 2 (2017): 187-206 
study by Rokhman and Ahamed ${ }^{32}$ of 300 undergraduates from four different faculties at the Islamic College of Kudus in Central Java, Indonesia has revealed that family background and social status are prominent and significantly influenced youth to become entrepreneurs. Therefore, the hypothesis to be tested in this study is:

$\mathrm{H}_{1}$ : Entrepreneurial intention has a positive influence on the sustainable development in the perspective of Islam.

\section{Entrepreneurial Intention}

The Theory of Planned Behavior (TPB) is the theoretical framework that widely used for the intention formation process and manifestation..$^{33}$ Tung $^{34}$ argues that other existing models such EIM, EPM, and SMEI models are obviously lack of empirical test, while EEM, revised EIM and TPB have been dominated in the field of entrepreneurship research. ${ }^{35}$ TPB clearly extends the antecedents of entrepreneurial intention to a social level while the revised EIM and EEM lacks information on this aspect. ${ }^{36}$

Ajzen, Czach, and Flood ${ }^{37}$ explain that a person's belief over an intended behavior is determined by three categories of indicators in modeling the antecedent of that intention. Those three types of individual beliefs that influence the process of intention are as follow:

32 W. Rokhman and F. Ahamed,"The Role of Social and Psychological Factors on Entrepreneurial Intention among Islamic College Students in Indonesia," Entrepreneurial Business and Economics Review, vol.3, no.1(2015):29-42.

33 I. Ajzen, "The Theory of Planned Behavior," Organizational Behavior and Human Decision Processes 50 (1991): 179-211.

${ }^{34}$ Lo Choi Tung, “The Impact Of Entrepreneurship Education On Entrepreneurial Intention Of Engineering Students" (Cityu University Of Hong Kong, 2012).Ibid.

35 M. Drnovsek and T. Erikson, "Competing Models of Entrepreneurial Intentions," Economic and Business Review 7, no. 1 (2005): 55-71.

${ }^{36}$ C. Chen, P. Greeene, and A. Crick, "Does Entrepreneurial Self-Efficacy Distinguish Entrepreneurs from Managers?," Journal of Business Venturing 13 (1998): 295-316; F. Wilson, J. Kickul, and D. Marlino, "Gender, Entrepreneurial Self-Efficacy, and Entrepreneurial Career Intentions: Implications for Entrepreneurship Education," Entrepreneurship Theory and Practice 31, no. 3 (2007): 387-406; H. Zhao, S. Seibert, and G. Hills, "The Mediating Role of Self-Efficacy in the Development of Entrepreneurial Intentions," Journal of Applied Psychology 90, no. 6 (2005): 1265-1272.

37 I. Ajzen, C. Czach, and M. G. Flood, "From Intentions to Behavior: Implementation Intention, Commitment, and Conscientiousness," Journal of Applied Social Psychology 39, no. 6 (2009): 1356-1372. 
(1) the beliefs of the consequences that may arise from an action (behavioral belief), (2) the belief of other expectations (normative beliefs) and (3) the belief in the existence of certain elements that can inhibit the emergence of certain actions (belief control). These three factors of confidence produce intention factors such as personal attitudes, social norms, and perceived behavioral control.

A lot of researchers have worked in the field of student (youth) intention towards entrepreneurship and confirmed the positive influence of these three antecedents of intention (personal attitude, subjective norms, and perceived behavioral control). Personal attitude is a reflection where someone has an evaluation or assessment of the likes or dislike behavior or which has more advantages, and there is a positive influence between personal attitudes and entrepreneurial intentions according to several studies that have been done. ${ }^{38}$ In contrast, ${ }^{39}$ Ridha and Wahyu found that attitudes toward behavior have small or no effect on entrepreneurial intention. Subjective norm is a social pressure that is obtained when doing or not doing a behavior. It means that entrepreneurial intention has a positive correlation with extraversion, openness, and support from the closest people who are part of the subjective norm factor. ${ }^{40}$ Furthermore, Moriano et al., ${ }^{41}$ suggest that individuals tend to be influenced by the

38 J.L.R. Robledo et al., "The Moderating Role of Gender on Entrepreneurial Intentions: A TPB Perspective," Omnia Science 11, no. 1 (2015): 92-117; K. Soon, A. Rahman, and N Nadia, "Theory of Planned Behavior: Undergraduates' Entrepreneurial Motivation and Entrepreneurship Career Intention at a Public University," Journal of Entrepreneurship: Research \& Practice (2016): 1-14.

39 Rizki Novanda Ridha and Budi Priyatna Wahyu, "Entrepreneurship Intention in Agricultural Sector of Young Generation in Indonesia," Asia Pacific Journal of Innovation and Entrepreneurship 11, no. 1 (2017): 76-89.

40 E. Masoomi et al., "An Investigation of the Factor Influencing Entrepreneurial Intention of Senior Agricultural Students at Shiraz Univerity, Iran," International Journal of Agricultural Management and Development 6, no. 4 (2016): 431-4374; R.M.S. Wijerathna, "Factors Predicting the Intention of Academics of Faculties of Agriculture in the State Universities in Sri Lanka to Engage in Outreach Activities," Tropical Agricultural Research 26, no. 2 (2015): 285-293; N. Shiri, M. Davoud, and H. Seyed, "Entrepreneurial Intention Of Agricultural Students: Effects Of Role Model, Social Support, Social Norms And Perceived Desirability.," Archives of Applied Science Research 4, no. 2 (2012): 892-897.

41 J.A. Moriano et al., "A Cross-Cultural Approach to Understanding Entrepreneurial Intention," Journal of Career Development 39, no. 2 (2011): 162-185. 
opinion of other in a collective culture. Meanwhile, perceived behavior control is a feeling easy or difficult of performing a behavior. This refers to a person's perception of taking the action needed to become an entrepreneur that usually combine the evaluation of skills, intellectual ability, and ability to overcome obstacles effectively. Prior researches have revealed their findings and concluded that perceived behavioral control has positive influence towards entrepreneurial intention. ${ }^{42}$ Hence, the following are hypothesized:

H2a : Personal attitude towards entrepreneurship positively influence the intention of the youths in Indonesia.

$\mathrm{H} 2 \mathrm{~b}$ : Subjective norms regarding entrepreneurship significantly effect the entrepreneurial intention among the youth.

H2c : Perceived behavioral control toward entrepreneurship positively influence the intention of the youth in Indonesia.

The following figure (Figure 1) illustrates the proposed model that is carried out by integrating the theory of TPB with its three construct variables and how the relationships between the construct variables in the maqusid al-shari $\bar{a}$ ah are examined and become references in the preparation of the hypotheses.

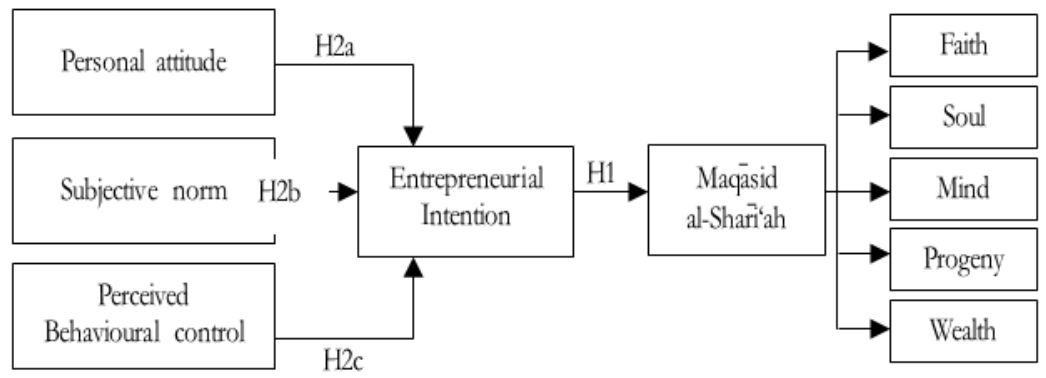

Figure 1. Research Model

42 A.S. Nabila and D. A. D Haryani, "Determinants of Entrepreneurial Intention Among Undergraduate Students in Malaysia," Procedia Economics and Finance 37, no. 16 (2016): 108-114; Grisna Anggadwita and Wawan Dhewanto, "Women's Entrepreneurial Intentions in Micro and Small Enterprises (MSEs) in Indonesia: The Influence of Environmental Factors on Perceived Behavioral Control," Journal of Administrative and Business Studies 1, no. 1 (2015): 1-7; M. Dabic et al., "Exploring Gender Differences In Attitudes Of University Students Towards Entrepreneurship: An International Survey," International Journal of Gender and Entrepreneurship 4, no. 3 (2012): 316-336. 


\section{The Alignment of Entrepreneurial Intention and Maqasid al- Shariah}

Through the Smart PLS, the proposed relationships in the research framework were tested. On the basis of the reflective and structural assessment measurements, it is concluded that the models fit the data at an acceptable level.

Table 1. Results of Hypotheses Testing

\begin{tabular}{clccc}
\hline Hypotheses & \multicolumn{1}{c}{ Path } & $\begin{array}{c}\text { T Statistics } \\
(\mid \mathbf{O} / \text { STDEV } \mid)\end{array}$ & P Values & Result \\
\hline $\mathrm{H} 1$ & $\mathrm{INT} \rightarrow \mathrm{M}$ & 9.029 & 0.000 & Accepted \\
$\mathrm{H} 2 \mathrm{a}$ & $\mathrm{PA} \rightarrow$ INT & 2.520 & 0.012 & Rejected \\
$\mathrm{H} 2 \mathrm{~b}$ & $\mathrm{SN} \rightarrow \mathrm{INT}$ & 8.633 & 0.000 & Accepted \\
$\mathrm{H} 2 \mathrm{c}$ & $\mathrm{PBC} \rightarrow \mathrm{INT}$ & 5.471 & 0.000 & Accepted \\
\hline
\end{tabular}

Source: Primary data analysis result

Based on the Table 1, figure 2 further shows that its $t$ value and $\mathrm{p}$ value meet the requirements of $\mathrm{P}<0.05$ and $-1.96>t>1.96$ for every instrument measured. The first objective in this study is to measure the correlation between intention and maqasid al-shari'ah and the result has revealed a positive influence of the youth intention to become entrepreneur in the future. This significance correlation is shown from the $\mathrm{P}$ value of 0.000 and $\mathrm{t}$ value of 9.029 , thus hypothesis 1 is supported.

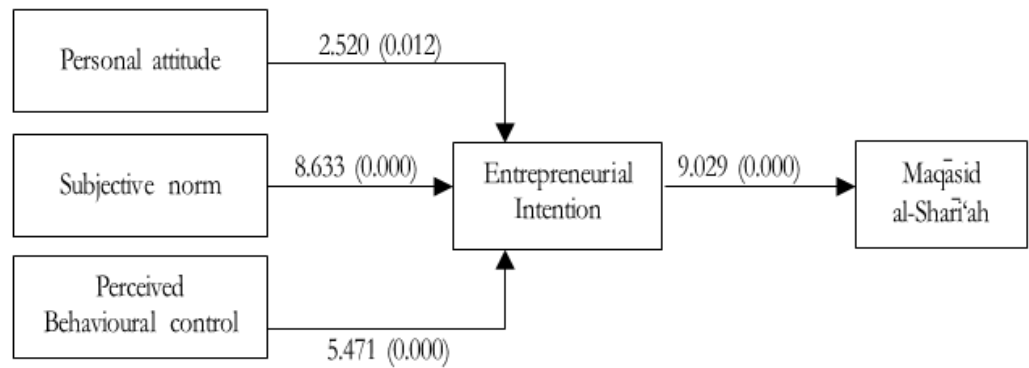

Figure 2. Path coefficient of research framework

The path coefficient of personal attitude toward intention to be an entrepreneur result assumes that personal attitude has no affect towards youth intention to build their own business with effect size of personal attitude in this study is 0.011 slightly below the threshold 
(0.02). As revealed also from the value of $\mathrm{P}(0.012$ slightly below the threshold of 0.05 ) and its $t$ value (2.52 slightly above the threshold of 1.96). The result is in line with a couple of researches conducted by some scholars such as Arisandi, Ridha and Wahyu ${ }^{43}$ that revealed personal attitude toward behavior has small or no effect on entrepreneurial intention. According to them, this infers that personal attitude cannot determine the intentions of entrepreneurs. Hence, the hypothesis $2 \mathrm{a}$ is not supported.

The hypothesis $2 \mathrm{~b}$ is analysing the correlation of subjective norms towards the creation intention to be entrepreneurs among the youth. The output implies that the subjective norm has a significant influence on their entrepreneurial intention. The hypothesis is supported with evidence of the $t$ value of $8.633(>1.96)$ and $p$ value of $0.000(<0.05)$. This result is consistent with several studies in the past which captured its significant relationship. ${ }^{44}$

The influence of perceived behavioural control to the entrepreneurial intention of the youth is confirmed with the $t$ value of $5.471(>1.96)$ and $\mathrm{P}$ value of $0.000(<0.05)$, therefore the hypothesis $2 \mathrm{c}$ is supported. This result suggests that intention depends on the belief in one's abilities, not with what skills someone's possess. The strong links between self-efficacy and behaviour have been found in the empirical research literatures among experts. ${ }^{45}$

${ }^{43}$ D Arisandi, "Intensi Berwirausaha Mahasiswa Pascasarjana Institut Pertanian Bogor Pada Bidang Agribisnis (Studi Kasus Pada Mahasiswa Program Magister Sps-Ipb)" (IPB University, 2016); Ridha and Wahyu, "Entrepreneurship Intention in Agricultural Sector of Young Generation in Indonesia."

44 O. Tateh, H.A. Latip, and Marikan D.A. Awang, "Entrepreneurial Intentions Among Indigenous Dayak in Sarawak, Malaysia: An Assessment of Personality Traits and Social Learning.," The Macrotheme Review 3, no. 2 (2014): 110-119; V. FernandezPerez et al., "Professional and Personal Social Networks: A Bridge to Entrepreneurship for Academics?," European Management Journal 33, no. 1 (2015): 3747; Masoomi et al., "An Investigation of the Factor Influencing Entrepreneurial Intention of Senior Agricultural Students at Shiraz Univerity, Iran"; Soon, Rahman, and Nadia, "Theory of Planned Behavior: Undergraduates' Entrepreneurial Motivation and Entrepreneurship Career Intention at a Public University."

45 N. Krueger, M. Reilly, and A Carsrud, "Competing Models of Entrepreneurial Intentions," Journal of Business Venturing 15 (2000): 411-432; Dabic et al., "Exploring Gender Differences In Attitudes Of University Students Towards Entrepreneurship: An International Survey"; Robledo et al., "The Moderating Role of Gender on Entrepreneurial Intentions: A TPB Perspective"; Nabila and Haryani, "Determinants of Entrepreneurial Intention Among Undergraduate Students in Malaysia.” 
Taking into account the elements of faith and moral in the consideration of youth to start their own business is one of the objectives of this study. Some of indicators represent the moral aspect of youth intention to become an entrepreneur and represented from the questions such as "I believe that in my wealth, there is other's right", "Being an entrepreneur, I can help other unfortunate people", and "Being an entrepreneur, I can create job to other people". These questions imply that their intention is not only for individual or their family benefits or solely for materialistic orientation, but also for moral responsibility for their community and surrounding society. ${ }^{46}$ Oukil asserts that the ultimate objective of human is to obey Allah by generating personal wealth and contributing to the well-being of others through endowments or/and other beneficial activities such as provide job opportunities that solely to seek blessings from God.

In the context of Indonesia as the most populated Muslim country, these faith and moral elements are able to become the prominent factors for encouraging the youths to become entrepreneurs after graduation from the university rather than seeking a job under the government institutions, banks or well-established companies. Particularly, youth empowerment programs should be a more targeted orientation to Islamic schools and institutions. By doing this, those youths who study in Islamic based schools are broaden their perspective that da'wa activity is not only carried out through religious sermon inside the mosque but it is likely to be done also through mu'amalab (interaction) in the business sectors for example, by providing the needy people a job that could secure them from poverty that can jeopardize their imān (faith).

In addition, among the three antecedents of intention towards behaviour to be entrepreneur, subjective norm has the highest impact followed by perceived behavioural control and attitude. Entrepreneurial intention is associated positively with extraversion, openness and support of people nearby which are under the subjective norm factor. ${ }^{47}$ Further, social learning theory shows that a person

\footnotetext{
46 M-said Oukil, "Entrepreneurship and Entrepreneurs in an Islamic Context," Journal of Islamic and Human Advanced Research 3, no. 3 (2013): 111-131.

47 Ismail, M. et al., "Entrepreneurial Intention among Malaysian Undergraduates," International Journal of Business Management 4, no. 10 (2009): 54-60.
} 
tends to adopt behaviour exemplified by family members, friends or even mentors, especially if the results of the behaviour are valued. ${ }^{48}$

Recently, entrepreneurship becomes one of the popular career options among the younger generation. By knowing the great potential of the youth to accelerate more entrepreneurs, one of the results in this study reveals specific characteristics of Indonesian youths to be used in various programs as well as policies. As the impacts, the increasing entrepreneur will bring significant changes specifically to the GDP, wealth in general, unemployment, and poverty. The World Bank has predicted that the ideal entrepreneurship for Indonesia is 4\% to reach an achievement and become a developed country, meanwhile its current total entrepreneurship is still at 1.6 percent and is left behind compare to other ASEAN countries for instance Singapore, Malaysia, Thailand, which have 7, 5, and 4.3 percent respectively, meanwhile Vietnam and Filipina are above 3 percent. Reasonably, if the amount of entrepreneurship is increasing, it will trigger multiplier effects in the economy such as entrepreneurship providing more job opportunities. The more availability of job opportunities, the more people have income to fulfil their daily needs, thus it will decline the unemployment rate, decrease the state's burden in terms of social expenditures, and increase the national income and eventually will positively affect the sustainable development.

Support from surroundings such as family, relatives and friends would approve their decision to start their own business. Start from home, the parents should change their paradigm that being government employee is the best option after graduating from the university and should start encouraging them to start their own business. Some of the classical yet out-dated reasons why parent push their sons or daughters to join the government institutions are salary, even though the rate is lower than what private employee gets, but it is safe and covers their life expenditures with pension allowances. This reason makes the government employee status to be a privilege. Although, being an entrepreneur, they can get salaries that are ten times higher or even more if they put a lot of hard work. Thus, the youths shall regularly educate and approach by entrepreneur figures with their struggling and success stories.

48 A Bandura, Social Learning Theory (Upper Saddle River, NJ: Prentice-Hall, 1977). 
With regarding to Indonesia as the most Muslim population in the world, religious activists and teachers together with the religion leaders shall consistently encourage the youngster that doing dawa is not always inside the mosque but providing benefits to others is another way of dawa for example by providing job opportunities for the poor thus they can fulfil their basic needs. Being a useful person is one of the characteristics that must be possessed by a Muslim. The Prophet Muhammad said: "the best of human is the most beneficial for other human."49

\section{Conclusion}

Entrepreneurial intention literature recently shows the importance of adapting intention models with other variable and apply them into entrepreneurship type-specific intention. ${ }^{50}$ This paper integrates the applicability of TPB and maqasid al-shari'ab toward sustainable development agenda. Hence, a model for entrepreneurial intentions with maqasid al-shari $\bar{i}^{\prime}$ h is proposed toward sustainable development agenda. The results of the study contribute to the sustainable and entrepreneurship literatures in some ways, as discussed earlier. The findings of the study also have implications for public policies and society through both formal and informal education in order to enhance their attitudes toward becoming entrepreneurs.

Firstly, the contribution of this research in the entrepreneurship literature is to show that the entrepreneurial intention model needs to be adapted to the specific entrepreneurial context. In the context of Indonesia as a very large Muslim community, the result of the study indicates that religious and moral motivations have become inseparable variables for developing entrepreneurial intentions among young people. In addition, material reason cannot be used as a mere motivation to become entrepreneur. However, there are also nonmaterial reasons for instance sharing benefits for others.

Secondly, the output of data analysis declares that subjective norms as the strongest driver to influence youth entrepreneurial intention.

\footnotetext{
${ }^{49} \mathrm{HR}$. Ah $\} \mathrm{mad}$, al-T\{Habra $>$ ni $>$ and al-Da $>$ ruqut $\}$ ni $>$. This $\mathrm{H}\{$ adi $>$ th is validated by al-Alba $>$ ni $>$ in $S\{a h\} i>h\}$ al-Ja $>$ mi' no: 3289 .

50 Francisco Linan and Alain Fayolle, "A Systematic Literature Review On Entrepreneurial Intentions: Citation, Thematic Analyses, And Research Agenda," International Entrepreneurship and Management Journal 11, no. 4 (2015): 907-933.
} 
This result also supports the social learning theory explaining that subjective norm is more dominant compared to two others antecedent in the collective culture which tend to influenced by the opinion of others. ${ }^{51}$ In this entrepreneurship context, when the person believes that referents (for example parents, friends or other relatives, entrepreneur figures) think an entrepreneur profession should be pursued, that person may change their belief on self-competency, business connection, capital, and government support to be positive toward entrepreneurship.

This study also contributes for entrepreneurship education. With the objective to enhance the level of entrepreneurial intention through education, attention should be paid on the subjective norm variable. Besides training and knowledge about entrepreneurship, parents are also particularly important to understand about entrepreneurship as a prospectus profession thus they can positively encourage their children to become entrepreneurs after completing their study. Another alternative, the youth should also have sharing session more often to get inspired from entrepreneurs who have succeeded in building their business.

This study has policy-level implications regarding the empowerment programs by the government. Nationally, 12 programs are made to develop the youths, comprising a core of youth empowerment, which by the Ministry of Youth and Sports (KEMENPORA) is divided into three segments, namely awareness, empowerment and development. Those programs as follow: 1) Independent Youth Builds Village (PMMD), (2) Kirab Nusantara of Youth (KPN), (3) Youth Beginner Entrepreneurship (WMP), (4) Youth E-Commerce Training, 5) Youth Organization Assistance (OKP), (6) Youth Appropriate District (KLP), (7) Youth Pioneer Mosque, (8) Development Bank of Music, (9) Master's degree Scholarship of Youth for Youth Organization Chief, (10) Overseas Internship of Youth Program (PPMLN), (11) Activity Support Asian Youth Day (AYD), (12) AntiNarcotics Youth. On the program of youth beginner entrepreneurship, the government facilitates as much as 1,000 start-ups to get financial assistance, supervising, consultancy to become great and successful entrepreneurs in the future. Besides that, this study suggests providing

51 Moriano et al., "A Cross-Cultural Approach to Understanding Entrepreneurial Intention.” 
more frequent motivational programs by success entrepreneurs or business mentors to foster the youth enthusiasm in doing business.

The youths are considered as the weakest part in the population because they are vulnerable to being expelled from the labor market as they are new entrants who have limited skills and experiences and if turbulence happens to the economy, this group of age frequently becomes the last element to be employed and sometimes become the first to be terminated.]

\section{References}

Ajzen, I. "The Theory of Planned Behavior." Organizational Behavior and Human Decision Processes 50 (1991): 179-211.

Ajzen, I., C. Czach, and M. G. Flood. "From Intentions to Behavior: Implementation Intention, Commitment, and Conscientiousness." Journal of Applied Social Psychology 39, no. 6 (2009): 1356-1372.

Anggadwita, Grisna, and Wawan Dhewanto. “Women's Entrepreneurial Intentions in Micro and Small Enterprises (MSEs) in Indonesia: The Influence of Environmental Factors on Perceived Behavioral Control." Journal of Administrative and Business Studies 1, no. 1 (2015): 1-7.

Apostolopoulos, N., H. Al-Dajani, D. Holt, P. Jones, and N.R. Jones. "Entrepreneurship and the Sustainable Development Goals." In Entrepreneurship and the Sustainable Development Goals, 1-7. Bingley, UK: Emerald Publishing Limited, 2018.

Arisandi, D. "Intensi Berwirausaha Mahasiswa Pascasarjana Institut Pertanian Bogor Pada Bidang Agribisnis (Studi Kasus Pada Mahasiswa Program Magister Sps-Ipb).” IPB University, 2016.

Asyraf, Hj Ab Rahman., Syahrin Said, Hailan Salamun, Hamdan Aziz, Fadzli Adam, and Wan Ahmad. Wan Ibrahim. "Sustainable Development From Islamic Perspective." International Joumal of Civil Engineering and Technology 9, no. 4 (2018): 985-992.

Azis, A., and A. R. Haerani. Peranan Bank Indonesia Di Dalam Mendukung Pengembangan Usaha Mikro, Kecil, Dan Menengah. Kebanksent. Jakarta, Indonesia: Pusat Pendidikan dan Studi Kebanksentralan (PPSK), 2009. 
Badruzaman, Abad. "Toward an Indonesian Current in Islamic Exegesis: An Attempt to Contextualize the Maqasid Al-Quran." Journal of Indonesian Islam 13, no. 2 (2019).

Bandura, A. Social Learning Theory. Upper Saddle River, NJ: PrenticeHall, 1977.

Bersaglio, B., C. Enns, and T. Kepe. "Youth Under Construction: The United Nations' Representations of Youth in the Global Conversation on the Post-2015 Development Agenda." Canadian Journal of Development Studies 36, no. 1 (2015): 57-71.

BPS. Statistical Yearbook of Indonesia, 2017.

Carsrud, A., and M. Braannback. "Entrepreneurial Motivations: What Do We Still Need to Know?" Journal of Small Business Management 49, no. 1 (2011): 9-26.

Chen, C., P. Greeene, and A. Crick. "Does Entrepreneurial SelfEfficacy Distinguish Entrepreneurs from Managers?" Journal of Business Venturing 13 (1998): 295-316.

Dabic, M., T. Daim, E. Bayraktaroglu, I. Novak, and M. Basic. "Exploring Gender Differences In Attitudes Of University Students Towards Entrepreneurship: An International Survey." International Journal of Gender and Entrepreneurship 4, no. 3 (2012): 316-336.

Dariah, Atih Rohaeti, Muhammad SyukriSalleh, and Hakimi M.Shafiai. "A New Approach for Sustainable Development Goals in Islamic Perspective." Procedia-Social Behavioral Sciences, no. 219 (2016): 159-166.

Drnovsek, M., and T. Erikson. "Competing Models of Entrepreneurial Intentions." Economic and Business Review 7, no. 1 (2005): 55-71.

Fernandez-Perez, V., P. E. Alonso-Galicia, L. Rodriquez-Ariza, and M. del Mar Fuentes- Fuentes. "Professional and Personal Social Networks: A Bridge to Entrepreneurship for Academics?" European Management Journal 33, no. 1 (2015): 37-47.

Gough, K., T. Langevang, and G. Owusu. "Youth Employment in a Globalising World.” International Development Planning Review 35, no. 2 (2013): 91-102.

Hair, J.F., T.M. Hult, C.M. Ringle, and M. Sarstedt. A Primer on Partial Least Square Structural Equation Modeling (PLS-SEM). Sage 
Publications, 2017.

Hendrie, A. "Introducing an Islamic Human Development Index (IHDI) to Measure Development in OIC Countries." Islamic Economic Studies 19, no. 2 (2011): 1-18.

Ibn Ashur, Muhammad Al-Tahir. Treatise on Maqasid Al-Shariah. Edited by Dr. Anas S. al-Shaikh-Ali and Shiraz Khan. IIIT Books. The International Institute of Islamic Thought (IIIT), 2013.

Ismail, M., S.A. Khalid, M. Othman, H. Jusoff, R.N. Abdul, K.M. Kassim, and R.S Zain. "Entrepreneurial Intention among Malaysian Undergraduates." International Journal of Business Management 4, no. 10 (2009): 54-60.

Khan, Z., and Z. Bahari. "Maqasid Shariah Based Development Index: A Posterity Dimension." In Policy Discussion Papers on Maqasid Shariah for Socio-Economic Development, edited by Abdul Ghafar Ismail, Salman Syed Ali, and Latifa Bibi. Saudi Arabia: IRTIIDB, 2016.

Klarin, Thomas. "The Concept of Sustainable Development: From Its Beginning to the Contemporary Issues." Zagreb International Review of Economics \& Business 21, no. 1 (2018): 67-94.

Krueger, N., M. Reilly, and A Carsrud. "Competing Models of Entrepreneurial Intentions." Journal of Business Venturing 15 (2000): 411-432.

Linan, F., and Y. W. Chen. "Development and Cross-Cultural Application of a Specific Instrument to Measure Entrepreneurial Intentions." Entrepreneurship Theory and Practice 33, no. 3 (2009): 593-617.

Linan, Francisco, and Alain Fayolle. "A Systematic Literature Review On Entrepreneurial Intentions: Citation, Thematic Analyses, And Research Agenda." International Entrepreneurship and Management Journal 11, no. 4 (2015): 907-933.

Masoomi, E., N. Zamani, K. Bazrafkan, and M Reza. "An Investigation of the Factor Influencing Entrepreneurial Intention of Senior Agricultural Students at Shiraz Univerity, Iran." International Journal of Agricultural Management and Development 6, no. 4 (2016): 431-4374.

Moriano, J.A., M. Gorgievski, M. Laguna, U. Stephan, and K. 
Zarafshani. "A Cross-Cultural Approach to Understanding Entrepreneurial Intention." Journal of Career Development 39, no. 2 (2011): 162-185.

Muller, T. "Religiosity and Attitudes Towards the Involvement of Religious Leaders in Politics: A Multilevel-Analysis of 55 Societies." World Values Research 2, no. 1 (2009): 1-29.

Nabila, A.S., and D. A. D Haryani. "Determinants of Entrepreneurial Intention Among Undergraduate Students in Malaysia." Procedia Economics and Finance 37, no. 16 (2016): 108-114.

Nizam, I., \& Larbani, M. “A Maqasid Shariah Based Composite Index to Measure Socio-Economic Prosperity in OIC Countries." In Policy Discussion Papers on Maqasid Shariah for Socio-Economic Development, edited by Abdul Ghafar Ismail, Salman Syed Ali, and Latifa Bibi. Saudi Arabia: IRTI-IDB, 2016.

Oukil, M-said. "Entrepreneurship and Entrepreneurs in an Islamic Context." Journal of Islamic and Human Advanced Research 3, no. 3 (2013): 111-131.

Raudha, M.R., A.G. Ismail, and M. Tasrif. "Maslahah-Based Development Index (M-Dex) Among The Islamic Countries." In Policy Discussion Papers on Maqasid Shariah for Socio-Economic Development, edited by Abdul Ghafar Ismail, Salman Syed Ali, and Latifa Bibi. Saudi Arabia: IRTI-Islamic Development Bank, 2016.

Remenyi, J. "What Is Development?" In Key Issues in Development, edited by D. Kingsbury, J. Remenyi, J. McKay, and J. Hunt, 22-44. Hampshire, New York: Palgrave Macmillan, 2004.

Ridha, Rizki Novanda, and Budi Priyatna Wahyu. "Entrepreneurship Intention in Agricultural Sector of Young Generation in Indonesia." Asia Pacific Journal of Innovation and Entrepreneurship 11, no. 1 (2017): 76-89.

Robledo, J.L.R., M.V. Aran, V.M. Sanchez, and M. AR. Molina. "The Moderating Role of Gender on Entrepreneurial Intentions: A TPB Perspective." Omnia Science 11, no. 1 (2015): 92-117.

Sachs, W. "Environment." In The Development Dictionary: A Guide to Knowledge as Power, edited by W. Sachs, 24-37. 2nd ed. London: Zed Books, 2010. 
Sharpley, R. "Tourism and Sustainable Development: Exploring the Theoretical Divide." Journal of Sustainable Tourism 8, no. 1 (2000): 1-19.

Shinnar, R. S., O. Giacomin, and F. Janssen. "Entrepreneurial Perceptions and Intentions: The Role of Gender and Culture." Entrepreneurship Theory \& Practice 36, no. 3 (2012): 465-493.

Shiri, N., M. Davoud, and H. Seyed. "Entrepreneurial Intention Of Agricultural Students: Effects Of Role Model, Social Support, Social Norms And Perceived Desirability." Archives of Applied Science Research 4, no. 2 (2012): 892-897.

Syafei, Zakaria. "Tracing Maqasid Al-Shari'ah in the Fatwas of Indonesian Council Of Ulama (MUI)." Journal of Indonesian Islam 11, no. 1 (2017).

Tangi, Sikandar. "Introduction to Development Studies." Scientific Network Academia.Edu.

Tateh, O., H.A. Latip, and Marikan D.A. Awang. "Entrepreneurial Intentions Among Indigenous Dayak in Sarawak, Malaysia: An Assessment of Personality Traits and Social Learning." The Macrotheme Review 3, no. 2 (2014): 110-119.

Todaro, M.P., and S.C. Smith. Economic Development. 8th ed. Harlow: Pearson Education limited, 2003.

Tung, Lo Choi. "The Impact Of Entrepreneurship Education On Entrepreneurial Intention Of Engineering Students." Cityu University Of Hong Kong, 2012.

United Nations. World Youth Report: Youth and the 2030 Agenda for Sustainable Development. New York, NY, 2017.

Zhao, H., S. Seibert, and G. Hills. "The Mediating Role of SelfEfficacy in the Development of Entrepreneurial Intentions." Journal of Applied Psychology 90, no. 6 (2005): 1265-1272.

"Core Indonesia." Accessed August 12, 2020. https://www.coreindonesia.org/view/468/waspada-lonjakan-pengangguran-dam $\% 1 \mathrm{~F}$ $\mathrm{pa}^{0} 1 \mathrm{Fk} \% 1 \mathrm{~F} \% 1 \mathrm{~F}-\% 1 \mathrm{~F} \% 1 \mathrm{Fpan} \% 1 \mathrm{Fdemi}$-covid-19-limarekomendasi-core. 